\title{
aniki
}

Revista Portuguesa da Imagem em Movimento

Portuguese Journal of the Moving Image

\section{Pedro Costa: The man (the circumstances) and his work}

\section{André Rui Graça}

Universidade da Beira Interior/Centro de Estudos Interdisciplinares da Universidade de Coimbra (CEIS20) andre.graca@ubi.pt

https://orcid.org/0000-0002-1028-5244

\author{
Barradas Jorge, Nuno. 2020. The \\ Films of Pedro Costa: Producing and \\ Consuming Contemporary Art \\ Cinema. Edinburgh: Edinburgh \\ University Press. 224 pp. ISBN \\ 9781474444538.
}

In this book, The Films of Pedro Costa: Producing and Consuming Contemporary Art Cinema, Nuno Barradas Jorge brings us face to face with Pedro Costa's biography and body of work - two things that seem to be intertwined. The author also dwells on the discussion about Costa's films and their ethos, as well as on the material circumstances in which the filmmaker has worked. In fact, the release of this book is rather timely: Barradas Jorge's contribution is the latest addition to a series of recent books, in English, on Portuguese cinema and/or Portuguese filmmakers. 
Featuring a relatively traditional, mainly chronological and easy-tofollow structure, this book, published by Edinburgh University Press, tells a story that needs to be systematised and told. Indeed, this work collects and processes much of what has been said and written on Pedro Costa, his films and his methods. While some theoretical hooks might not be completely new to Portuguese readers (who are already familiar with the film criticism around Pedro Costa), the text enjoys the kind of cohesion and reasoning rhythm that monographs are known to provide - which is useful - and the author sets out to explain and discuss the different production contexts that have shaped Costa's work since his directorial debut - which, the author claims, is a gap that needs to be filled.

In a way, this is a plunge into the different phases of the filmmaker. The book opens with the description of the portrait of the filmmaker as a young man and is followed by a contextualisation of the different material circumstances and intellectual predisposition in which Costa's first films were produced and shot- in this book we keep track of the sources of inspiration (from both Portuguese and international filmmakers) that have shaped Costa's cinematic thought throughout the years (Bresson, Wenders, Rossellini, Tarr, Silva Melo and Oliveira, among others). We are also often confronted with the scenario of precarity that has defined Portuguese cinema. From Blood (O Sangue, 1989) to Horse Money (Cavalo Dinheiro, 2014) Barradas Jorge serves as a distinguished cicerone through the aesthetic, material, and ideological development of both the auteur and his films - "Costa's evolving authorial process", as Jorge puts it. Comprehending all of the important stages of the filmmaker's career (i.e. his films or other audio-visual works), this book invites us to look for more than meets the eye - as per usual when one resorts to so many facets of film theory.

Unlike some other works on Pedro Costa and his films, Barradas Jorge writes a book that summarises many ideas that are scattered through various places and languages, in an accessible way, to a wider audience. This is perhaps its major strength. Although the text is very centred around Pedro Costa, this work is keen on offering insights into questions and themes that Costa and his oeuvre call for, such as the idiosyncrasies of the Portuguese film milieu, topics related to his films (immigration, precarity, etc.) and the international art-house film circuit. As we progress through the book, we realise that the angles of approach begin to change - even if ever so slightly - and Barradas 
Jorge starts to mediate a dialogue between film production, material circumstances, artistic intention and Costa's personal ideas. For instance, in Chapter 4, where Colossal Youth (Juventude em Marcha, 2006) is brought to the fore, emphasis is given to questions concerning film reception and artistic prestige - which means that this book will explore many facets of the film world reality. We can see that this multidisciplinary approach is in full swing when the topic of distribution reappears in Chapter 6 to show how Costa and his entourage explored different ways to address the international arthouse film circuit in the early 2000s. Retrospectives in film festivals and galleries/museums, home video (DVD) releases of his works and screenings followed by Q\&A sessions with Costa (which promoted the dialogue between audiences and the filmmaker) are all part of the circulation circumstances that marked Costa's career. Indeed, Costa is often presented as a master of experimentation in all possible realms of his métier.

On a more critical note, Barradas Jorge's motivation in this book seems to be tightly linked to how he and the other academic references he closely follows have been puzzled by Costa's cinematic style and besotted with his persona. In other words, the whole book is based on the premise that Pedro Costa is already a canonical filmmaker. Perhaps this explains Costa's hagiographic presentation and a somewhat biased tone that appears from time to time. To some readers, this might be seen as the book's main weakness. However, this tone might be appealing and well suited to certain target audiences that might be relatively unfamiliar with Portuguese cinema or are fierce supporters of Costa's oeuvre.

In the very first pages of his book, Barradas Jorge highlights what is perhaps one of the most interesting aspects in this discussion: Pedro Costa is identified, first and foremost, as an academic phenomenon especially one that struggles to exist and be debated outside a certain hermetic ecosystem, since he and his films have been cornered for many years in academic and cinephile niches. In the very first page, the author writes: "Whilst accruing critical esteem and the support of a burgeoning international fan base, Costa's exposure remains limited to cinephile fringes around the art-house and film festival circuits. Moreover, and as with other contemporary filmmakers catering mostly to boutique cinephiles, his creative output also finds receptive audiences on a variegated international circuit composed of academic- 
related venues, art galleries and museums" (p. 1). The author adds that this "seems to provoke further accusations commonly levied by some critics that his work is cinema for a cinephile elite, excessively formalist and incompressible by nature" (p. 2). This, in turn, raises another issue related to the old duality between academia and the nonacademic or non-cinephile world, i.e., that despite many efforts to bridge the gap between academia's ivory tower and society in the last decades, sometimes they seem to be just too far apart - usually much to some scholars' chagrin.

The fact that so many scholars, film critics and even renowned filmmakers advocate for Pedro Costa's work is a kind of pressure that is difficult to ignore or escape from; maybe that is one of the reasons why the book echoes the typical, worshipping discourses of Pedro Costa's supporters a great deal. Although, truth be told, we can see often the author struggling to detach from that kind of discourse and bring new stuff to the table.

A good example of that can be found in Chapter 5. While discussing Costa's work for the art gallery circuit, the author draws a parallel between these pieces and the short films directed by Costa between 2009 and 2012. Instances such as these are, arguably, the most interesting parts of Barradas Jorge's work: it is when the angle of analysis shifts from the discussion of already established ideas to the exploration of works that so far have not garnered much attention that things get particularly interesting (especially for readers who are more or less familiar with Pedro Costa's work and previous literature around it). Barradas Jorge's research, which also tackles the Portuguese film milieu and questions regarding film reception, is thorough and wellgrounded - and the author deserves credit for that.

Interestingly enough, works like this help consolidate Costa's position as Portugal's leading filmmaker in terms of interest and relevance (in cinephile and academic contexts). To some extent, I would argue that such texts induce me into thinking Pedro Costa seems to have quickly taken Manoel de Oliveira's place as the most prominent, celebrated and international Portuguese filmmaker. We will have to wait to see if this is just a passing moment or if the filmmaker and his body of work will endure the test of time and maintain cult-like status (and eventually attain some popular acclaim).

Ultimately, this is a journey through the life and work (as well as through the reception of that work, the modes of production and the 
distribution strategies) of one of Portugal's most polarising film directors. For many, Pedro Costa is a hard sell. For a few, he is a really easy one. Yet, regardless of how one feels about the filmmaker and his films, this is a must-read book. If you are already versed in Portuguese cinema, this book will invite you to revisit some of its major topics (that have been raised by many other scholars, especially Paulo Cunha, Jacques Lemiére, Daniel Ribas, Leonor Areal and Paulo Filipe Monteiro, among many others) and will add to that previous knowledge with a thorough and insightful account of Pedro Costa's career. If you are a newcomer, this book might be a good gateway - which will hopefully satisfy your curiosity about Pedro Costa in particular and win your interest in Portuguese cinema in general. 